\title{
A LIGHT AND ELECTRON MICROSCOPIC STUDY OF THE PAROTID GLAND IN DIFFERENT AGE GROUPS OF THE ALBINO RAT
}

\author{
Hemmat A. Abdel Hamid, Iman H. Abdel-Aal and Shahira Samir Zaki ' \\ Anatomy Department, Faculty of Medicine, Ain Shams University
}

\section{INTORDUCTION}

Major salivary glands are characterized by the presence of numerous excretory units that consist of acini and a peculiar duct system. The excretion of saliva is assisted by the myoepithelial cells which play an important role in the morphology of several kinds of salivary gland tumors (MartinezMadringal and Micheau, 1989). Although the rat salivary glands are deficient in acini at birth, acinar cells proliferate rapidly during the early postnatal period (Klein, 1982).

The parotid gland is one of the rat salivary glands and its parenchyma consists of serous acini, intercalated ducts and excretory ducts (Mazurova, 1983). Previous studies on the development of the parotid gland in various mammals have demonstrated that the terminal clusters and acini contained mucous cells during early postnatal period. However, little information has been available concerning the exact fate of the secretory granules in mucous cells, specially as whether or not the mucous cells differentiate into serous cells (Ikeda and Aiyama, 1997). In their study on the parotid gland in the juvenile Japanese macaque, Ikeda et al. (2001) found that mucous cells were converted into serous cells. The structure of the parotid gland in old aged mice was studied by Meisel et al. (1988). They found that in salivary glands, intracellular lipofuscin granules and residual body formation increased with age.

Sjogren' syndrome is a systemic autoimmune disease characterized by patient complaints of oral and ocular dryness accompanied by clinical observations of a progressive loss of salivary and lacrimal function related to the presence of a focal, periductal leucocyte infiltrate (HumphreysBeher et al., 1998). Abnormal fat deposition was observed in the parotid and submandibular salivary glands associated with Sjogren syndrome (Izumi et al., 1997). Attention should be paid to distinguish aging changes that occurred in the salivary gland and Sjogren syndrom's histopathological changes, specially in patients over 60 years old (Chen, 1993).

Salivary glands like many other organs undergo changes in structure with age. However, a comparison between the structure of the parotid gland (acini and ducts) in different ages from early postnatal days to senile 
ages received little attention. Therefore, it became the aim of the present work to study the development of the parotid gland in the albino rat from birth to senility and to determine the structural changes of the parotid gland at different age groups using both light and electron microscopy.

\section{MATERIAL AND METHODS}

The present study was based on the material obtained from male offsprings of ten pregnant females albino rats obtained from the animal house of faculty of medicine, Ain Shams University. Five male animals were sacrificed on each of following ages: one day, seven days, two weeks, one month and three months (adult). Another three senile animals two years old were also sacrificed. The newly born animals were left with their mothers in house cages until weaning at one month. The animals were maintained under conditions of controlled light and humidity, they were fed with commercial rat pellets and water.

\section{METHODS}

\section{Histological studies:}

The parotid glands from different age groups were dissected out and were processed for light microscopy. Three ages were chosen for electron microscopic study; 1 day, adult and senile.

\section{Light microscopy:}

The glands were fixed in $10 \%$ formol saline for $7-10$ days. Fixed tissues were dehydrated, cleared and embedded in paraffin blocks. Sections of $5 \mathrm{um}$ thickness were cut and stained with haematoxylin and eosin ( $\mathrm{Hx} \&$ E). (Drury and Wallington, 1982).

\section{Electron microscopy:}

The glands were cut into small pieces and fixed for $2-4$ hours in $2.5 \%$ glutaraldehyde in $0.1 \mathrm{M}$ phosphate buffer ph 7.2. Fixed tissue samples were washed with the same buffer and post fixed in $1 \%$ osmium tetraoxide in 0.1 phosphate buffer for one hour and then washed in the same buffer. After dehydration in ascending grades of alcohol and embedding in epon. semithin sections (1 um) were cut using LKB ultramicrotome, stained with toluidine blue, examined and photographed by Olympus $286 \mathrm{M}$ light microscope. Ultrathin sections were cut and stained with uranyl acetate and lead citrate (Reynolds, 1963). The grids were examined and photographed with Philips 201 Transmission Electron Microscope Unit at Medical Military Academy. 


\section{RESULTS}

\section{One day:}

The parotid gland at this age was formed of clusters of cells and ducts arranged into lobes and lobules. They were surrounded by ill defined capsule which could be identified in some sites and not present in others. The lobes were separated from each other by wide spaces filled with diffuse connective tissue (Figs. 1,2). The component cells of each cluster were arranged into more than one layer. Some clusters acquired a small lumen but others had no visible lumen (Fig. 3). Budding of some cells could be seen in different areas raised from the ducts (Fig. 4). At this age, the duct system was differentiated into two components namely intercalated ducts which were located intralobularly and interlobular ducts. The intercalated ducts which were hardly detected from the clusters could be recognized by their much smaller size and their wider lumina. The intercalated ducts were lined with cubical epithelium with rounded nuclei (Figs. 2,5). The interlobular ducts had a wide lumen and were lined with pseudostratified columnar epithelium in some sites and columnar epithelium in other sites. The epithelium was formed of dark and light cells. Numerous fibroblasts could be identified in the area surrounding the clusters and ducts outside their basal lamina i.e. in the connective tissue (Fig. 6). Myoepithelial cells could be easily demonstrated inside the basal lamina of both clusters and ducts, they might appear fusiform or spider like depending on the plane of section (Figs. 3,4).

The ultrastructure of the parotid gland at this age revealed the presence of clusters of small sized cells containing large nuclei which occupy most of the cytoplasm. Few cells had secretory granules. A small amount of rough endoplasmic reticulum and a dense cytoplasmic population of free ribosomes were present. The rough endoplasmic reticulum was very short and scattered throughout the cytoplasm. The Golgi complex was small in size consisted of few and very short cisternae with small nearby vesicles. Mitochondria were moderate in size and in number (Fig. 7).

The intercalated ducts were lined with one layer of cuboidal cells, sometimes with two layers of cuboidal cells. The ductal cells contained the same organelles as the cluster cells, however they were fewer in number and smaller in size compared with those of the cluster cells. Secretory granules couldn't be detected in the intercalated duct, lateral cellular processes were found between ductal cells (Fig. 8). The interlobular ducts were lined by columnar cells in some sites and pseudostratified in other sites (Fig. 9). Lateral cellular processes and desmosomes were observed between the ductal cells and microvilli were found to project into the lumen of the duct (Fig. 10). Myoepithelial cells could be easily identified separating both acinar and duct cell from their basal lamina. They contained mitochon- 
dria and had processes connecting them with the acinar cells. They were surrounded with connective tissue containing collagen fibers (Fig. 11).

The structure of the parotid gland at seven days was almost similar to its structure at two weeks but it was smaller in size.

\section{Two weeks:}

At this age, the gland appeared more compact. The amount of the connective tissue separating the lobes and lobules was reduced. There was also an increase in the number of acini per lobule as compared with the previous age. Moreover, the apical cytoplasmic eosinophilia and basal basophilia became manifested, the intercalated duct and the interlobular ducts were easily identified (Figs, 12, 13). Most of the clusters presented the characteristic features of the serous acini, each consisted of a single layer of nearly pyramidal cells around a very small central lumen. The nuclei were basally located. Some clusters of cells were still present specially at the periphery of the lobules. The blood vessels were invested in the connective tissue septa. Mitotic figures were still seen in some acinar cells. The most characteristic feature of that age was the presence of dark secretory granules in the apical portion of the acinar cells. The interlobular ducts were lined with pseudostratified columnar epithelium. Two types of cells were recognized namely dark and light cells. The dark cells were fewer in number and were located in the outer layer (Figs. 14, 15).

The parotid gland at one month age nearly achieved the character of the adult gland with the exception of its relatively smaller size.

\section{Adult (3 months):}

There was a continuous generalized increase in the size of the gland. The number of the undifferentiated clusters showed marked reduction and the interparenchymal connective tissue was further reduced in amount. The apical eosinophilia and basal basophilia of the acini were more prominent than the previous age with apparently enlarged acini (Fig. 16). The intercalated ducts were easily recognized from the acini than in the previous age. They were lined with cuboidal cells surrounding a distinct lumen (Fig. 17). The striated ducts couldn't be detected in all age groups.

Electron microscopy revealed an apparent increase in the acinar cell size and its contained internal organelles specially the rough endoplasmic reticulum which was increased in amount and basally located. There was also an apparent increase in the secretory granules mostly of the dark type (Figs. 18, 19). The lateral cellular surfaces as shown in the previous age exhibited cytoplasmic processes (Fig. 19). The myoepithellial cells were also demonstrated overhanging both acinar and ductal cells inside the basal lamina (Fig. 20). 


\section{Senile age:}

There was no increase in the size of the gland or acini than the previous age. An apparent decrease in the number of acini per lobule and loss of some acini in some areas of the gland were observed. As regards the duct system, there was a relative increase in the number of ducts compared to the acini in some parts of the gland. The lining epithelium of these ducts consisted of flat cells (Fig. 21). Hypertrophy and vacuolation of some acinar cells with duplication of their nuclei were also presented (Fig. 22).

Electron microscopic examination of this age revealed that there was an accumulation of lipid droplets in the acinar cells (Fig. 23). Plasmalemma of some acinar cells was almost straight all around and the cytoplasmic processes in between these cells couldn't be observed. However, the adjacent cells were sealed with prominent junctional complexes. The cytoplasm in some cells was packed of secretory granules of moderate electron density (Fig. 24). As regards the cell organelles inside the acinar cell, the rough endoplasmic reticulum was arranged basally in parallel rows. Other cells showed marked dilatation and vesiculation of the rough endoplasmic reticulum, degenerated mitochondria and irregular dark nuclei with condensed chromatin were also observed. Most of cells showed the presence of electron lucent granules that might coalesce together forming large vacuoles (Fig. 25, 26).

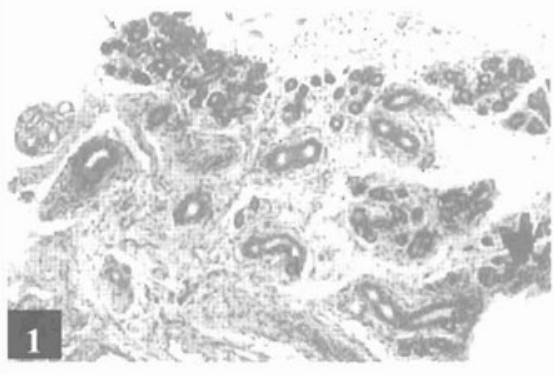

Fig. (1): Photomicrograph of a section of the parotid gland of one day old male albino rat showing the arrangement of clusters of cells (c) and ducts (d) arranged into lobes and lobules separated by connective tissue cells and fibers. The capsule is ill defined $(\uparrow)(H \times \& E ; X 100)$

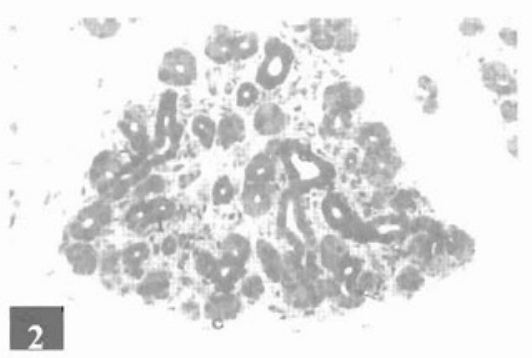

Fig. (2): Photomicrograph of a section of the parotid gland of one day old male albino rat showing the cluster of cells (c), intercalated ducts (1) and interlobular ducts (d). Note the mitotic figures ( $\uparrow$ ) (Toluidine blue; X 200) 


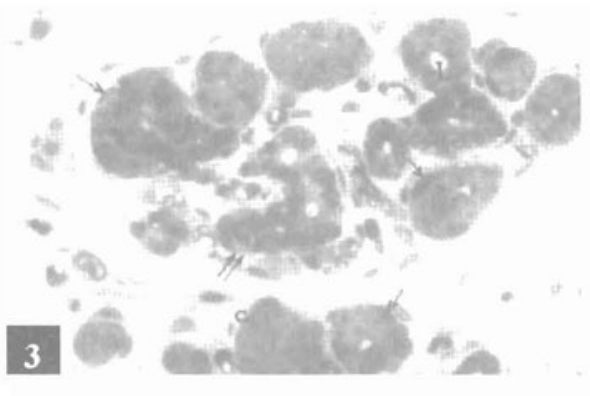

Fig. (3): Photomicrograph of a semithin section of the parotid gland of one day old male albino rat showing the lobules containing the glandular tissue in the form of clusters of cells without lumen (c). Some clusters acquiring a lumen (L). Note the mitotic figures in some cells $(\uparrow \uparrow)$, and the myoepithelial cells $(\uparrow)$ in the clusters. (Toluidine blue; X 400).

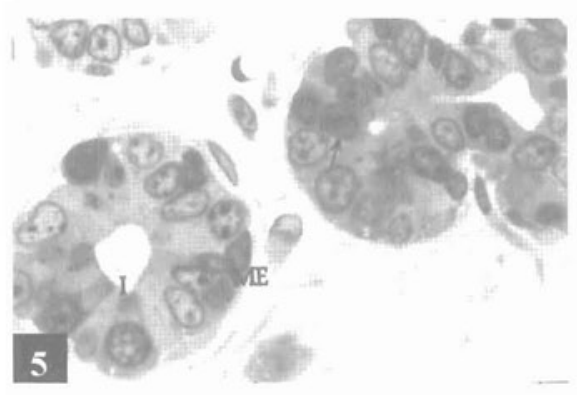

Fig. (5): Photomicrograph of a semithin section of the parotid gland of one day old male albino rat showing the interlobular duct (I). Note the mitotic figures in some clusters of cells $(\uparrow)$ and myoepithelial cells (ME). (Toluidine blue; X 1000)

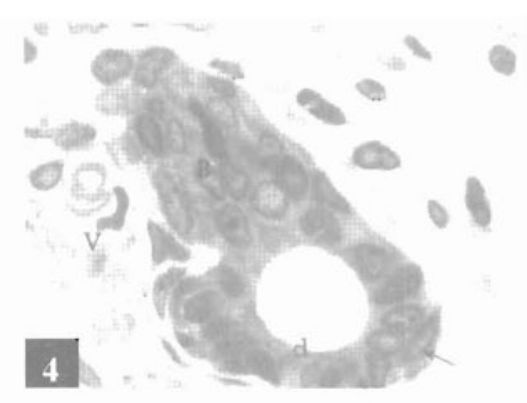

Fig. (4): Photomicrograph of a semithin section of the parotid gland of one day old male albino rat showing the interlobular duct (d) surrounded by connective tissue containing blood vessels (V). Note the budding of some cells (B) out from the duct. Myoepithelial cells can be seen near the basal lamina of the duct (-). (Toluidine blue; $X$ 1000).

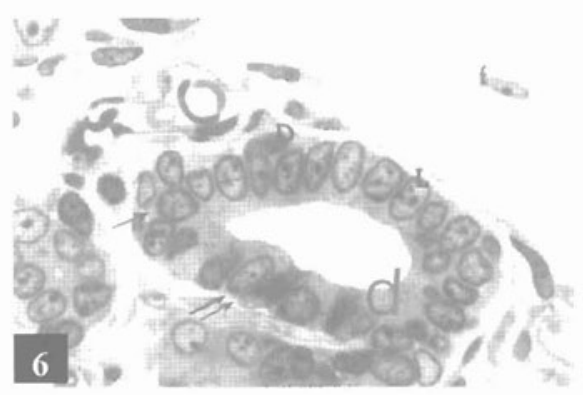

Fig. (6): Photomicrograph of a semithin section of the parotid gland of one day old male albino rat showing the interlobular duct (d). The lining epithelium is pseudostratified in some sites $(\uparrow)$ and columnar in other sites $(\uparrow \uparrow)$. The cells are in the form of light (L) and dark cells (D). The fibroblasts (f) have long processes. (Toluidine blue; $\times 1000$ ) 


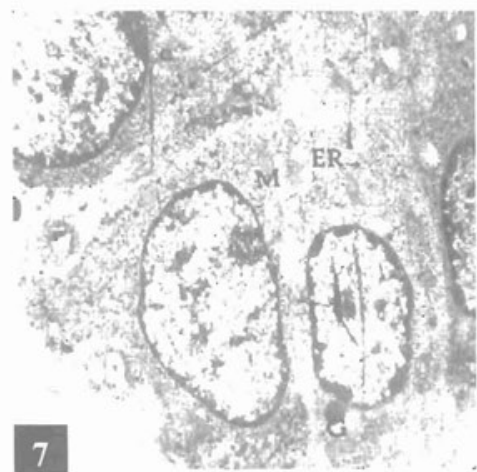

Fig. (7): Electron micrograph of the parotid gland of one day old male albino rat showing the cells of the clusters. Secretory granules are few in number $(G)$, rough endoplasmic reticulum (ER) is present in short segments and abundant unattached ribosomes. Note the mitochondria (M) and Golgi complex (C). (Lead citrate \& urany1 acetate; X 4000)

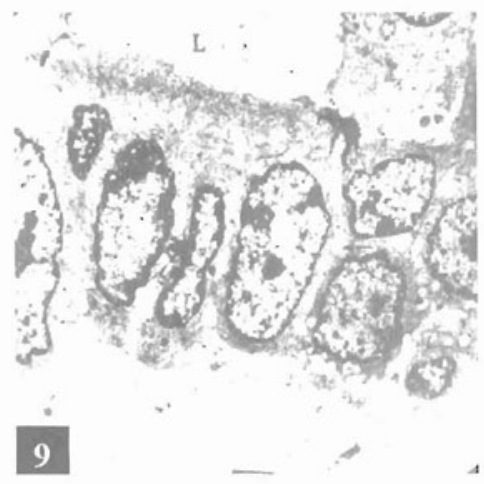

Fig. (9): Electron micrograph of the parotid gland of one day old male albino rat showing a portion of an intercalated duct. Note the lining epithelium sometimes columnar and sometimes pseudostratified surround-ing a lumen $(L)$ and lateral cellular processes $(\uparrow)$. (Lead citrate \& urany1 acetate; X 4000)

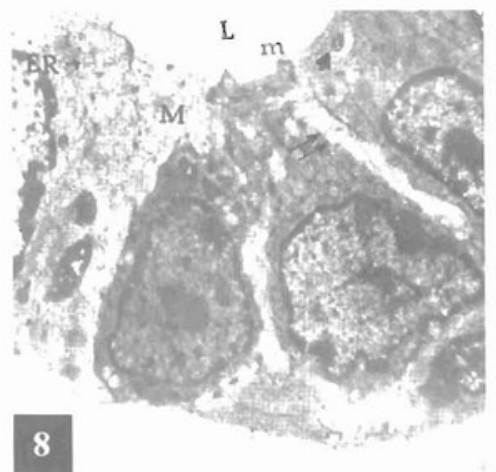

Fig. (8): Electron micrograph of the parotid gland of one day old male albino rat showing a portion of an intercalated duct. Note the presence of few segments of rough endoplasmic reticulum (ER), mitochondria (M), lateral cytoplasmic processes $(\uparrow \uparrow)$, wide lumen $(\mathrm{L})$ with microvilli $(\mathrm{m})$ and myelin like figures $(\uparrow)$. (Lead citrate \& urany1 acetate; $X$ 4000)

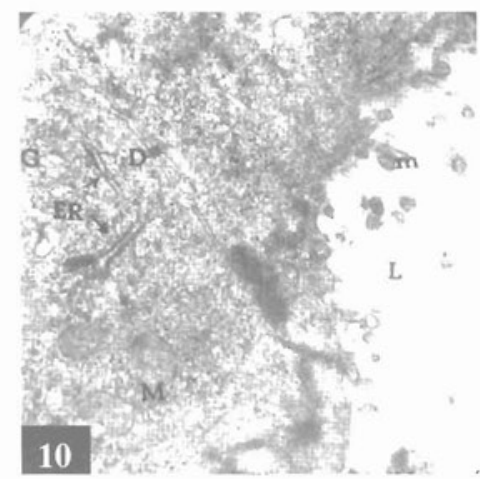

Fig. (10): Electron micrograph of the parotid gland of one day old male albino rat showing the luminal surface of interlobular duct cell. Note the presence of rough endoplasmic reticulum (ER), mitochondria (M). Golgi complex (G) wide lumen (L) with numerous microvilli $(\mathrm{m})$ and desmosomes (D). (Lead citrate \& urany1 acetate; $X 15000$ ) 


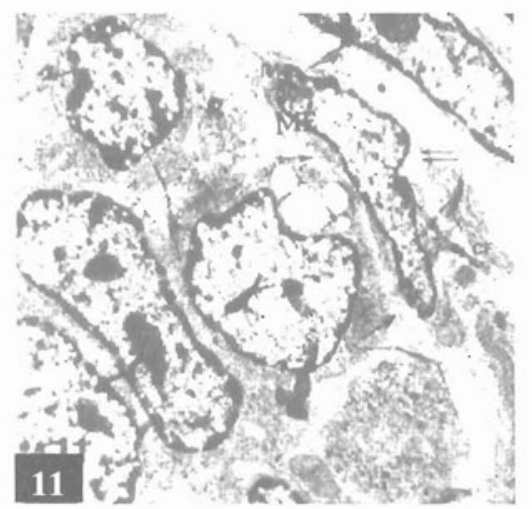

Fig. (11): Electron micrograph of the parotid gland of one day old male albino showing the structure of myoepithelial cell (ME). It lies between the cells of the acinus and the basal lamina $(\uparrow \uparrow)$. Note the presence of processes that connect it with the acinar cell $(\uparrow)$. Note also mitochondria (M) and collagen fibres (CF). (Lead citrate \& urany1 acetate; $X$ 4000)

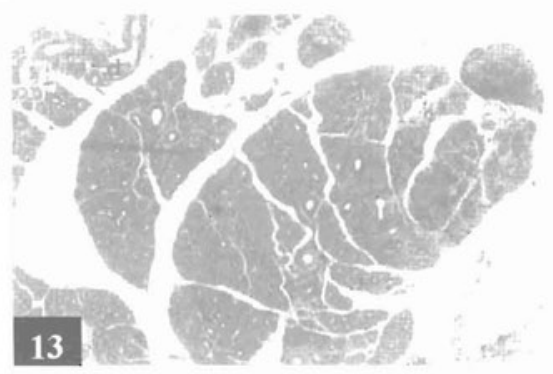

Fig. (13): Photomicrograph of a semithin section of the parotid gland of two weeks old male albino rat showing the intercalated duct (I) and the interlobular duct (d). (Toluidine blue; X 100)

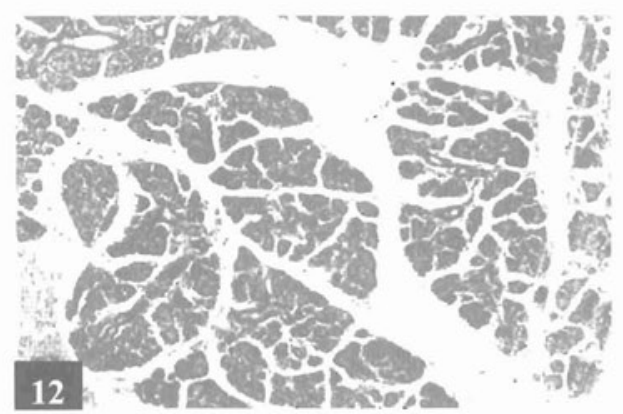

Fig. (12): Photomicrograph of a section of the parotid gland of two weeks old male albino rat showing the arrange-ment of acini and ducts into lobes and lobules with reduced amount of connective tissue than the previous age. Note the basal basophilia and apical eosinophilia among the acinar cells. ( $H x \& E ; X$ 100)

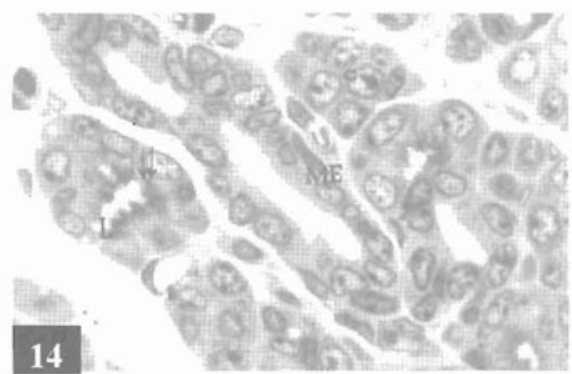

Fig. (14): Photomicrograph of a semithin section of the parotid gland of two weeks old male albino rat showing the arrangement of acinar cells into one layer with large rounded basal nuclei with a lumen (L). Some cluster of cells (c) are still present at the periphery. Secretory granules appear as blue dots near the lumen $(\uparrow \uparrow)$. Note the myoepithelial cells (ME). (Toluidine blue; X 1000) 


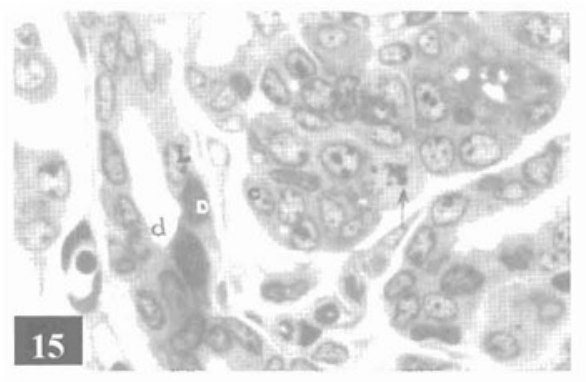

Fig. (15): Photomicrograph of a semithin section of the parotid gland of two weeks old male albino rat showing the cluster of cells (c) are still present at the periphery. Some cells appear with mitotic figures $(\uparrow)$. The interlobular duct (d) lined with pseudostratified columnar epithelium with dark (D) and light cells (L). (Toluidine blue; X 1000)

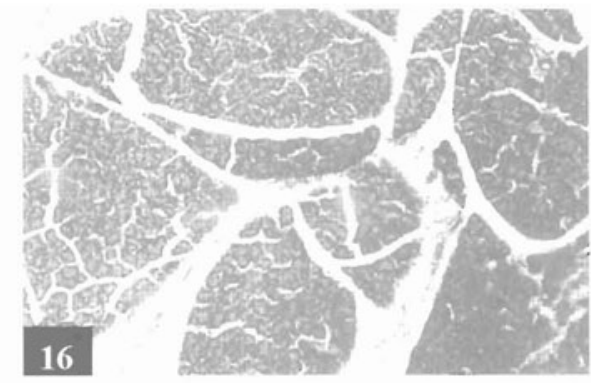

Fig. (16): Photomicrograph of a section of the parotid gland of an adult ( 3 months) male albino rat showing the arrangement of acini and ducts into lobes and lobules separated by connective tissue septa. (Hx \& E; X 100)

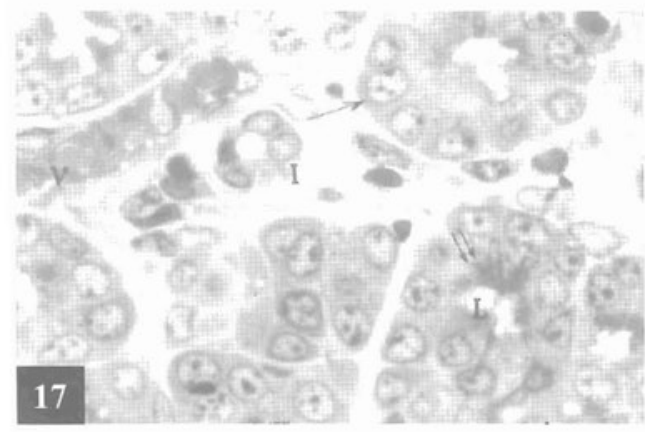

Fig. (17): Photomicrograph of a semithin section of the parotid gland of an adult ( 3 months) male albino rat showing the arrangement of acinar cells into one layer with large rounded basal nuclei $(\uparrow)$. Note the intercalated duct (I) and the apical granules ( $\uparrow$ ) near the lumen $(L)$. note also a blood vessel (v). (Toluidine blue; X 1000)

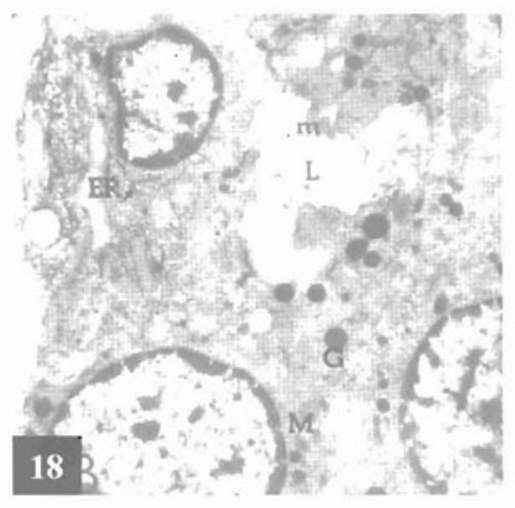

Fig. (18): Electron micrograph of the parotid gland of an adult ( 3 months) male albino rat showing an acinus. Note the presence of dark secretory granules (G), rough endoplasmic reticulum $(E R)$, lumen $(L)$ with microvilli $(m)$ and mitochondria (M). (Lead citrate \& urany1 acetate; X 3000) 


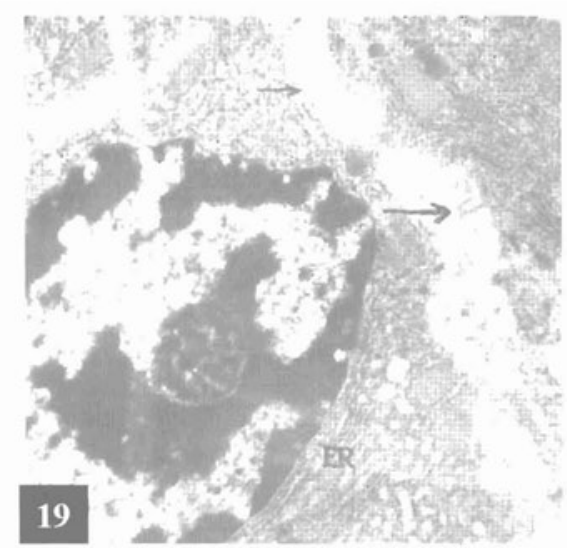

Fig. (19): Electron micrograph of the parotid gland of an adult ( 3 months) male albino rat showing the lateral cellular surface in an acinus. Note the cytoplasmic processes $(\uparrow)$ and the rough endoplasmic reticulum basally located in the cell (ER). (Lead citrate \& urany 1 acetate; X 8000)

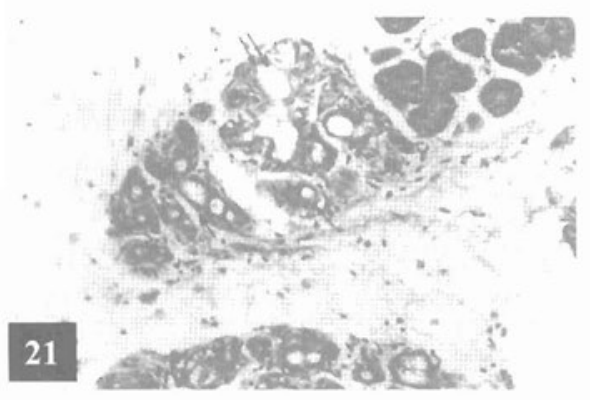

Fig. (21): Photomicrograph of a section of the parotid gland of a senile male albino rat showing area of the gland with decreased number of acini. The duct system is apparently increased in number. Its lining epithelium is flat $(\uparrow)$. Note also loss of some acini in the tissue $(\uparrow \uparrow)$. (Hx \& E; X 200)

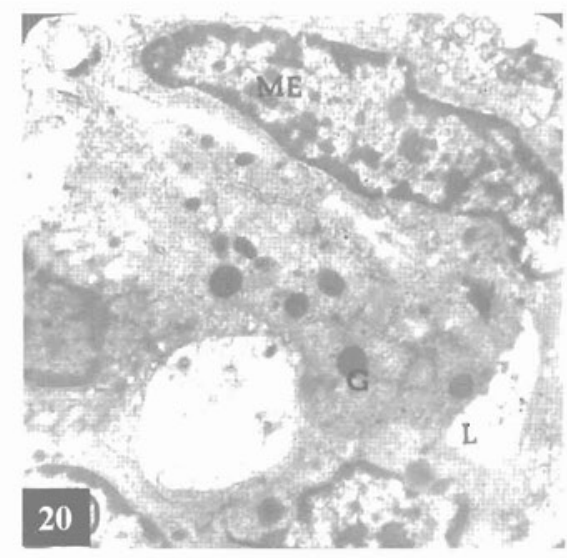

Fig. (20): Electron micrograph of the parotid gland of an adult ( 3 months) male albino rat showing an acinus cell. Note the myoepithelial cell overhanging the acinus (ME), granules $(G)$ and lumen (L). (Lead citrate \& urany1 acetate; X 6000)

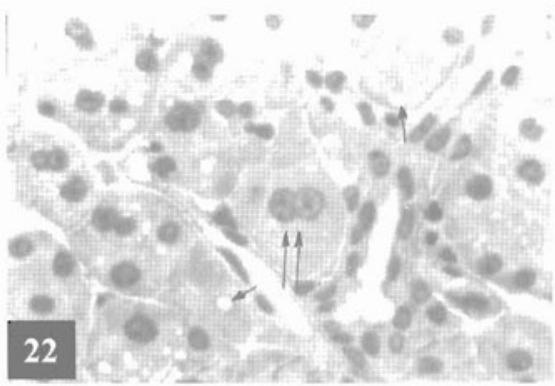

Fig. (22): Photomicrograph of a semithin section of the parotid gland of a senile male albino rat showing vacuolation in some acini $(\uparrow)$. Note the hypertrophy of some acinar cells with double nuclei $(\uparrow \uparrow)$. (Toluidine blue; $\times 400$ ) 


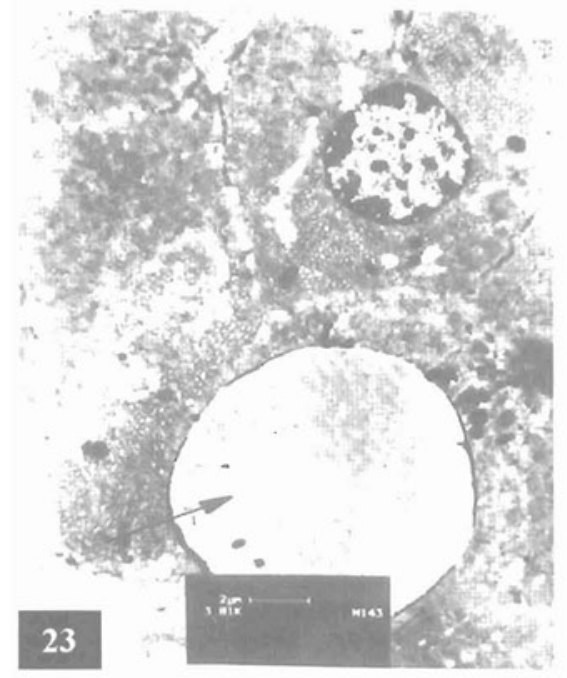

Fig. (23): Electron micrograph of the parotid gland of a senile male albino rat showing a large lipid droplet $(\uparrow)$ in the acinar cell. (Lead citrate \& urany1 acetate; X 3800)

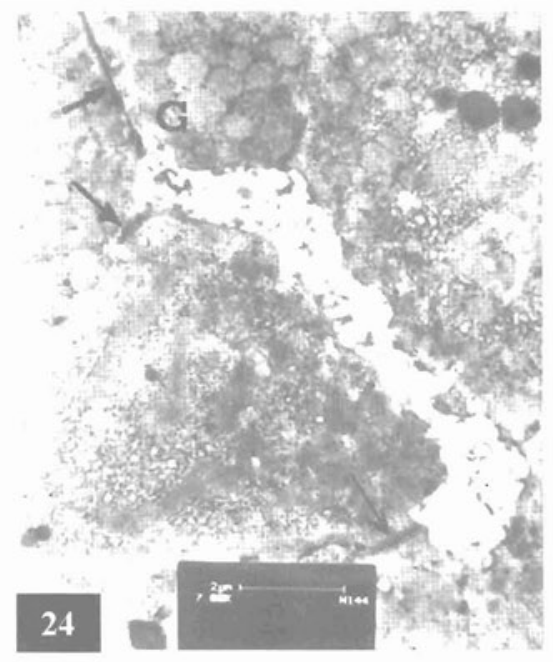

Fig. (24): Electron micrograph of the parotid gland of a senile male albino rat showing acinar cells. Note that some adjacent acinar cells were sealed with prominent junctional complexes $(\uparrow)$. Note also granules $(G)$. (Lead citrate \& urany1 acetate; $X 7000)$

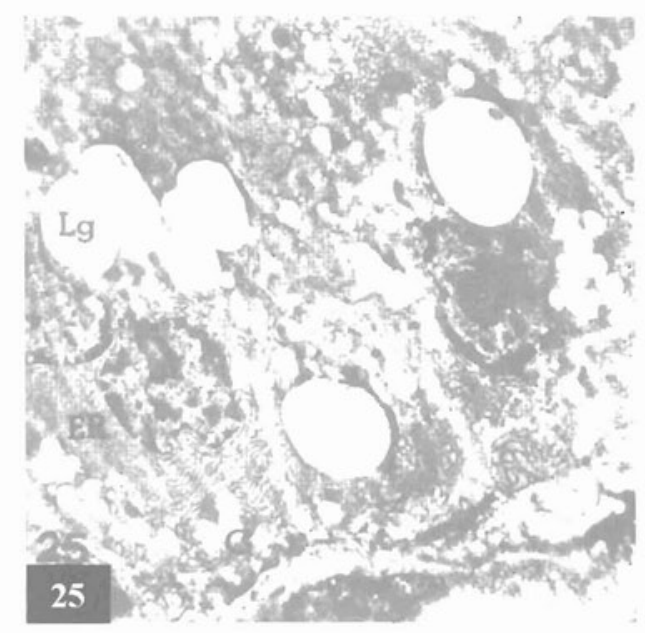

Fig. (25): Electron micrograph of the parotid gland of a senile male albino rat showing the presence of electron lucent granules $(G)$ and coalesced large granules $(\mathrm{Lg})$ forming large vacuoles. Note the rough endoplasmic reticulum (ER) basally located. (Lead citrate \& urany1 acetate; X 3000) 


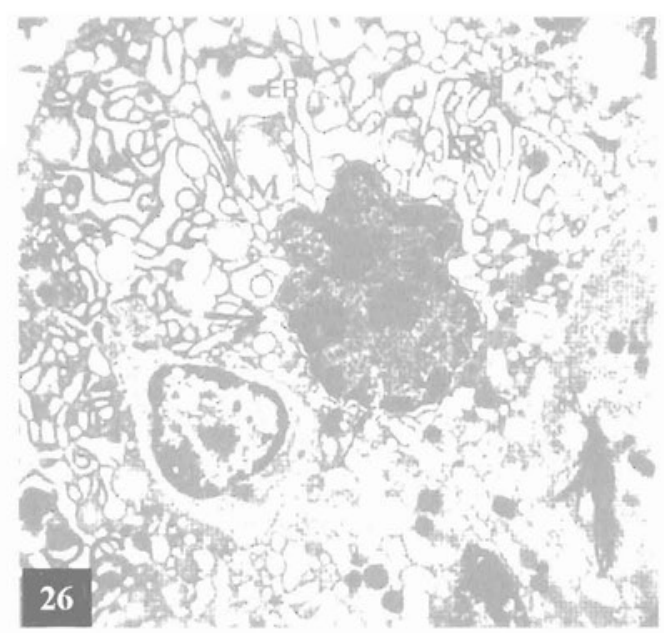

Fig. (26): Electron micrograph of the parotid gland of a senile male albino rat showing acinar cells. Note the partially damaged mitochondria (M), vesiculated and dilated rough endoplasmic reticulum (ER) and the irregular dark nuclei $(\uparrow)$. (Lead citrate \& urany1 acetate; X 3000)

\section{DISCUSSION}

In the present study, the parotid gland of one day postnatal age consisted of clusters of cells and ducts arranged into lobes and lobules. The parotid gland showed extensive growth during the first week after birth as there was an increase in the number of acini on the expense of connective tissue. At one month, the acini assumed the adult mature form with the exception of their relatively smaller size. These results are in accord with Redman and Sreebny (1971) who stated that there were two periods of rapid growth and differentiation of the parotid gland: the first period from birth to 12 days and the second from 15 to 25 days. These two periods coincided respectively with the onset of suckling and weaning suggesting that substances in the food and secretory stimulation have an inductive significance on the differentiation of the gland.

In the present study, the acini of the parotid gland were formed of cells which appeared exclusively serous in nature, rounded nuclei lay within the basal cytoplasm which acquired basal basophilia. This is in agreement with Ragab (1987) in her study of the development of the rat parotid gland.

In the present work, examination of the parotid gland at one day revealed budding of some cell clusters from the duct or from the other clusters. This could be seen in different areas of the gland. This could be confirmed by Moore and Persaud (1998) who stated that in salivary gland, the primordium arose as an epithelial bud that grew by branching into bush-like 
system of solid ducts, whose end twigs rounded out into berry-like secretory acini.

Mitotic figures were observed in the present work at birth and could be seen till the age two weeks after which could not be detected denoting marked increase in cellular proliferation at the first two weeks of life. According to Schneyer and Hall (1969). Extensive cellular proliferation in the rat parotid gland was observed in the first three weeks of life with small increase in cell size. After this age the increase in the cell size became the prominent cellular event and mitotic rate decreased markedly.

Previous studies have reported that mucous cells could be seen in the terminal portion of the early postnatal parotid gland in humans and rats (Aiyama et al., 2000). These cells disappear as the gland develop. However, in the present study no mucous cells could be detected, which could be explained by the different method the authors used in fixing the tissue which was rapid freezing followed by freeze-substitution fixation.

The present study aggregation of free ribosomes (polysomes) in the cytoplasm of the acini in the parotid gland of one-day rats, that reflected high protein synthesis. Also, Golgi complex was well developed in the parotid gland of one- day rats denoting the start of secretory function. This was in accord with Tamaki et al. (2002) who stated that the morphogenesis of the Golgi apparatus could be recognized in the developmental process as well as in mitotic division of parotid acinar cell. They added that electron microscopic studies detected an aggregation of small vesicles in the early stages of postnatal development that appeared to be the rudimental element of Golgi apparatus.

Striated ducts were not demonstrated in the parotid gland of the present work. Pinkstaff (1980) reported in his international review that some salivary glands in mammalian species appeared to be without striated ducts. However, he said that these ducts were quite prominent in the human parotid and submandibular gland but were absent in sublingual glands.

In the present work the myoepithelial cells were easily seen with light and electron microscopy since birth overhanging the acinar and ductal cells just beneath the basal lamina, they were spindle shaped with their longitudinal axis lying perpendicular to the long axis of the ductal and acinar cells. Murakami et at. (1990) mentioned that the myoepithelial cells of the rat parotid were linked with one another forming a well developed network and suggested that myoepithelial cells in the intercalated duct might function as a protective wall against constriction of the narrow lumen of the intercalated duct, when it is subjected to pressure by surrounding tissue. Also Krause (1996) stated that the myoepithelial cells in human parotid gland located 
between the lining basement membrane and the bases of the secretory units might aid in expressing secretions out of the secretory units into the duct system.

In the present study, the senile age was characterized by some degenerative changes as the disappearance of some acini, fatty infiltration and vacuolation inside the acinar cells. Similar results were observed by Martinez-Madrigal and Micheau (1989) who reported that age induced variations and reactive changes including oncocycte proliferation, fatty infiltration, squamous and mucous metaplasia. They added that an analysis of the normal salivary gland structure permitted a morphogenetic approach to an understanding of the variability in histologic types of salivary gland tumors. Izumi et al. (1997) also observed abnormal fat deposition in the parotid and submandibular salivary glands associated with Sjogren's syndrome. Chen (1993) observed that acinar atrophy, duct dilatation, fat tissue, hyperplasia, fibrosis and lymphocytic infiltration were found to be agerelated changes of lip salivary gland. Tomographic measurement of age changes in the human parotid gland was studied by Drummond et al. (1995). They found a significant fall in the gland density. They postulated that the fall in the gland density was related to an increase in fibro-fatty tissue within the gland. Scott et al. (1987) studied the histological changes in human parotid gland. They noticed that advancing age was accompanied by acinar atrophy, duct irregularities and increase in adipose content.

They added that these structural age changes resembled those of other salivary glands, but unlike the latter were not accompanied by agedependent functional impairments. They suggested a greater acinar secretory efficiency or larger secretory reserve in the parotid than in other glands.

The rough endoplasmic reticulum was present as few segments at one day after birth. Its amount increased greatly in adult gland and it occupied a basal portion of the cell, which account for the basal basophilia observed by light microscopy (Han and Holmsteat, 1981). The present study showed also that in senile group, the rough endoplasmic reticulum was markedly dilated or arranged in compact parallel layers. Irregular dark nuclei with condensed chromatin were also observed. Riva and Testa (1973) found that the cells which contained rough endoplasmic reticulum in compact parallel rays had a nucleus with dispersed chromatin, while the dilated reticulum tended to be associated with nuclei having condensed chromatin. They attributed these variations to the presence of a secretory cycle similar to that observed in the human mucous glands.

The present study revealed that the plasmalemma of the acinar cells showed lateral cellular processes, while in the senile group the plamalemma in some cells was smooth all around. These lateral cellular 
processes might increase the surface area of the secretory acinar cell and their absence in the senile glands might proceed acinar atrophy observed by Williams et al. (1994). As regards the secretory granules, the present work revealed that in adult parotid gland, they were discrete, rounded in shape with high electron density. In senile age some of them had moderate electron density, while most of them were electron- lucent granules which might coalesce together forming large vacuoles. Young and Van Lennep (1978) classified glandular cells according to their secretory granules. They considered them serous if their granules were small, discrete and electron dense, seromucous if they had large electron- lucent and electron- dense granules. Clare et al. (1997) in their study on the lacrimal gland, also observed that the majority of the acini were serous in the young glands, while in senile rats there was a high percentage of mucous acini.

In the present work, some specimens in the senile rats showed hypertrophy of acinar cells and duplication of some nuclei. This finding was also observed by Saleh (2001) in her study on the lacrimal gland of senile rat. Water et al. (1996) explained this phenomenon as cell injury which might lead to burst of DNA synthesis. This was termed unscheduled DNA synthesis and if the cell survived, normal function would be usually restorted. However, some damage might be present, which could lead to metaplasia and neoplasia.

In conclusion, the present results put forward evidence to suggest that acinar and duct system of the parotid gland undergo progressive aiterations with age. Sjogren's syndrome is also known to show some histopathological changes in the parotid gland like abnormal fat deposition (Izumi et al., 1997). These histopathological changes must be distinguished from aging changes that occurs in the parotid gland especially in patients over 60 years old.

\section{SUMMARY}

The aim of the present work was to study the development of the parotid gland in the albino rat from birth until senility to determine the structural changes of the parotid gland at different age groups. The parotid glands were extracted from the white rats aged one day, seven days, two weeks, one month, three months and two years, and were examined by both light and electron microscopes.

The results showed that the acini were increased in size and in number with advance in age reaching the adult characters at one month. The undifferentiated clusters were greatly reduced in number with advance in age. There was also a progressive reduction in the amount of the interparenchymal connective tissue. As regards the duct system, both intercalated and interlobular ducts were gradually increased in number. Ultrastructur- 
ally, the cytoplasm in both the acini and ducts of one day old rats contained scanty rough endoplasmic reticulum, mitochondria and Golgi system. In three months old rats, it was noticed that there was prevalence of the rough endoplasmic reticulum, and increase in secretory granules.

Parotid glands of the senile group (two years) showed manifested degenerative changes in the form of vacuolation inside the acinar cell with accumulation of lipid droplets. Acinar cells in some lobules disappeared being replaced by fibrous tissue. Moreover, there was a relative increase in the duct system and their lining epithelium changed into flat and low cuboidal cells with widening of their lumina. Most of the secretory granules were electron- lucent and might coalesce together.

The results were discussed in the light of the previous literature, and it was concluded that the acinar cells of the parotid gland undergo progressive alterations with age. These findings might help to distinguish aging changes in the parotid gland from the pathological changes that occurs in the parotid gland associated with Sjogren syndrome.

\section{REFERENCES}

1. Aiyama, S.; Ikeda, R.; Matsuoka, T.; Kikuchi, K. and Koike, K. (2000): fine structure of transforming- type granules in mucous cells in the early postnatal rat parotid gland when processed by rapid freezing followed by freeze- substitution fixation. Anat. Rec., 260: 387- 391.

2. Chen, H. (1993): Age-related changes of human lip salivary glands and their values in the diagnosis of Sjogren syndrome. Zhongguo $\mathrm{Yi}$ Xue Ke Yuan Xue Bao. 15 (5): $343-348$.

3. Clare, E.; Jaipaul, S. and Pallot, D. (1997): The effect of age on protein secretion of the lacrimal gland. J. Physiol., 501: 155p.

4. Drummond, J.R.; Newton, J.P. and Abel, R.W. (1995): Tomographic measurements of age changes in the human parotid gland. Gerodontology, 12 (1): $26-30$.

5. Drury, R.A.B. and Wallington, E.A.F. (1982): Carleton's Histological Techniques. 4th ed., Oxford, University press, London.

6. Han, S.S. and Holmsteat, J.O.V. (1981): Human Microscopic Anatomy. McGraw-Hill Book Company, Chap. 17, 359- 362.

7. Humphreys-Beher, M.G.; Yamchika, S.; Yamamoto, H.; Maeda, N.; Nakagawa, Y.; Peck, A.B. and Robinson, C.P. (1998): Salivary gland 
changes in the NOD mouse model for Sjogren's syndrome: is there a non-immune genetic trigger? Eur. J. Morphol. 36 (suppl): $247-251$.

8. Ikeda, R. and Aiyama, S. (1997): Developmental changes in mucous cells of the early postnatal rat parotid gland: An ultrastructural and histochemical study. Arch. Histol. Cytol., 60 (2): 185-193.

9. Ikeda, R.; Aiyama, S.; Tsujimura, T. and Okamoto, K. (2001): developmental changes in the fine structure and histochemical properties of mucous cells in the parotid gland of the infant Japanese macaque. Arch. Histol. Cytol., 64 (5): 545- 553.

10.Izumi, M.; Eguchi, K.; Nakamura, H.; Nagataki, S. and Nakamura, T. (1997): Premature fat deposition in the salivary glands associated with Sjogren syndrome: MR and CT evidence. AJNR Am. J. Neuroradiol., 16 (5): $951-958$.

11.Klein, R.M. (1982): Acinar cell proliferation in the parotid in the submandibular salivary glands of the neonatal rat. Cell and Tissue kinetics, 15 (2): $187-195$.

12.Krause, W.J. (1996): Essential of Human Histology. 2nd ed., Little, Brown and company, Boston, New York, 262- 265.

13.Martinez-Madrigal, F. and Micheau, C. (1989): Histology of the major salivary glands. Am. J. Surg. Pathol., 13 (10): 879- 899.

14.Mazurova, Y. (1983): The S.E.M. study of rat parotid gland parenchyma. Zeitschrift Fur Mikroskopisch. Anatomische Forschung, 97 (4): $626-639$.

15.Meisel, D.L.; Skobe, Z.; Prostak, K.S. and Shklar, G. (1988): A light and electron microscopic atudy of aging parotid and submandibular salivary glands of Swiss-Webster mice. Exp. Gerontol., 23 (3): $197-210$.

16.Moore, K.L. and Persaud, T.N. (1998): The Developing Human: Clinically oriented embryology. 6th ed., W.B. Saunders company, Philadelphia, London, : $335-336$.

17.Murakami, M.; Nagato, T. and Tanioka, H. (1990): A scanning electron microscope study of myoepithelial cells in the intercalated ducts of the rat parotid and extraorbital lacrimal glands. Oka Jimas-folia Anat. Jpn., 67 (5): $309-314$.

18.Pinkstaff, C.A. (1980): The cytology of salivary glands. International Review of Cytology, 63: 142-259. 
19.Ragab, S. (1987): Studies on the development of parotid gland. Thesis submitted for ph. D. Degree, Anatomy Depatment, Faculty of Medicine, Minia University, Minia, Egypt.

20.Redman, R.S. and Sreebny, L.M. (1971): Proliferative behavior of differentiating cells in the developing rat parotid gland. J. Cell Biol., 46: 8187.

21.Reynolds, E.S. (1963): The use of lead citrate at high ph as an electron- opaque staining in electron microscopy. J. Cell Biol., 17: 208. 


\section{الملخص الصربى}

دراسة الغذة النكفية للقأر الأبيض في أعمار مختلفة

$$
\text { باستخدام المجهر الضوئي والكتروني }
$$

همت عبد الثادر عبد الحميد، إيمان حسين عبد العال، شهيرة سمير زكي

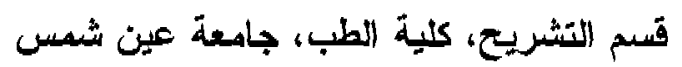

كان الهدف من هذا البحث هو در اسة نطور الغدة النكفية في الفأر الأبيض منذ

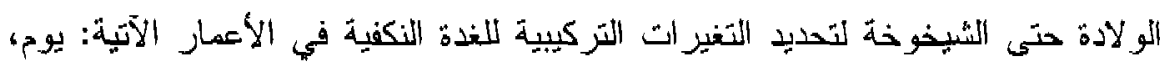

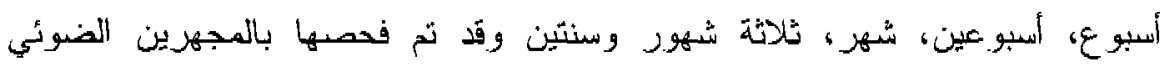
و الالكنزونهي.

وقد أظهرت النتائج أنه بالتقدم في العمر يزداد حجم و عدد الحويصلات وتقل نسبة

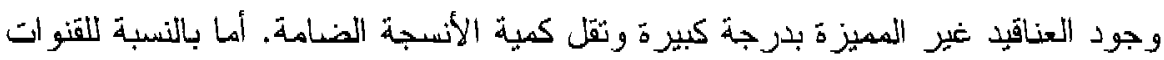

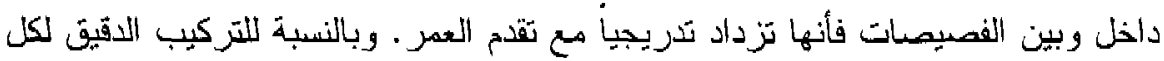

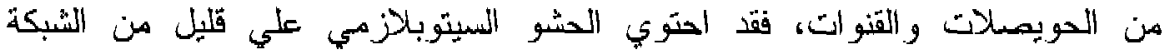

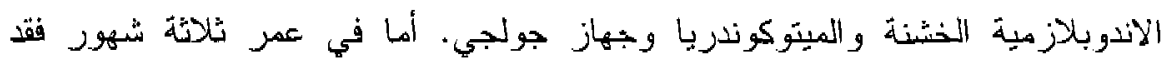
لوحظ انتشار الثبكة الاندويلازمية الخشنة وزيادة في الحبيبات الإفر ازية. وقد اظهر عمر الثيخوخة في الغدة النكفية (سنتين) تغيرات انحية الحلالية علي هيئة

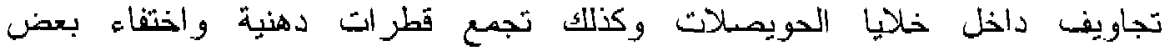

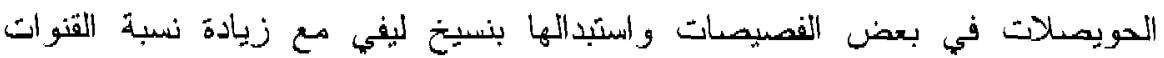

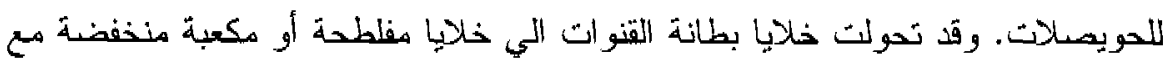

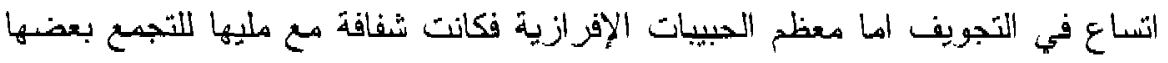

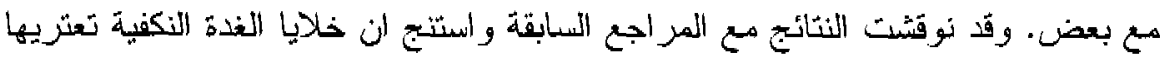

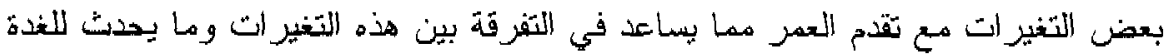
النكفية من تغير ات مرضية في ظاهرة جو جرين.

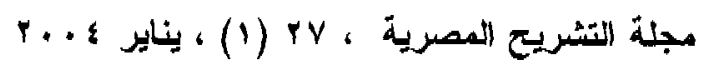

